\title{
Model evaluation of methods for Varroa jacobsoni mite control based on trapping in honey bee brood
}

\author{
J.N.M. Calis*, W.J. Boot, J. Beetsma \\ Department of Entomology, Wageningen Agricultural University, \\ P.O. Box 8031, 6700 EH Wageningen, the Netherlands
}

(Received 2 September 1998; accepted 1 February 1999)

\begin{abstract}
Biotechnical Varroa mite control methods are based on the principle that mites inside brood cells are trapped and can then easily be removed from a honey bee colony. Here, a validated trap-comb model based on work on invasion rates of mites into brood cells is used to estimate and compare effectiveness of different trap-comb methods. Trapping with worker brood is labour intensive because a large amount of brood is needed to trap a sufficient number of mites for effective control. In addition, trapping with worker brood requires subsequent treatment of the capped brood to selectively kill the mites, because beekeepers want to save the brood. Trapping with drone brood demands fewer brood cells for effective mite control, and destruction of drone brood with trapped mites is common practice. Moreover, preparation of trap-combs with drone brood can be integrated into swarm-prevention techniques and will take little extra time. (C Inra/DIB/AGIB/Elsevier, Paris
\end{abstract}

Apis mellifera / Varroa jacobsoni / trap-combs / biotechnical control / model

\section{INTRODUCTION}

If the parasitic mite, Varroa jacobsoni Oud. (Acari: Varroidae), infests colonies of European honey bees (Apis mellifera L.), control measures are required to maintain healthy colonies. Acaricide treatment of colonies, as practised world-wide, effectively diminishes mite populations [24], but may contaminate bee products $[4,19,21$, 27] and select for acaricide resistance [28, 31]. Environmentally safer acaricides such as formic, lactic and oxalic acid can also be successfully applied to control Varroa mites $[1,13,22,25,32]$. However, contamination may still occur [20], and due to their corrosive nature, handling is not without risk.

\footnotetext{
* Correspondence and reprints

E-mail: Johan.Calis@users.ento.wau.n1
} 
Control of mite populations without application of chemicals is the most environmentally safe option and is feasible because mites can be trapped inside brood cells and removed from a colony. This principle is used in biotechnical mite control methods.

Originally, trap-comb methods used as little worker brood as possible to trap the mites because the trap-combs were destroyed and beekeepers wanted to limit brood destruction. Maul [29] developed a system in which the queen is trapped in a cage that contains only one empty worker comb. The comb is replaced three or four times every 9 or 7 days, respectively. The combs along with the trapped mites are removed from the colony after capping. However, tests of this control system over several years showed that the level of mite populations continued to increase $[15,30]$.

Worker brood used for trapping can be saved, because mites trapped can be selectively killed by both high temperature treatment [33] or formic acid treatment of the brood combs outside the colony [14]. Selectively killing mites inside brood cells has opened ways to improve trap-comb methods using worker brood because an unrestricted amount of brood could be used to trap mites [7, 12].

Trap-combs with drone brood can also be used for $V$. jacobsoni control. Generally, many more mites are found per drone cell than per worker cell $[18,37,38]$ and Boot et al. [3] found that the invasion rate of mites into drone brood cells is about 12 times higher than the invasion rate into worker brood cells.

Trap-combs with drone brood have been used in colonies actively rearing brood [11, 36]. Although population growth decreased in these colonies, effective control was not achieved probably due to the presence of other brood. Trap-comb efficiency is low in colonies rearing brood for two reasons. First, the majority of the mites will be inside brood cells [17], and they cannot be trapped until their hosts emerge. Second, the brood being reared by the colony in the non-trap combs is also attractive to the mites and will compete with trap-combs. This insight promoted the use of trap-combs with drone brood in broodless colonies, which appeared to be much more effective $[5,6,8,10,23$, 34].

The effectiveness of trap-comb methods depends on the fraction of mites that invade brood on trap-combs. Boot et al. [2, 3] found that the rate of invasion of mites into brood cells is proportional to the ratio between the number of attractive brood cells and the number of bees in a colony. Calis et al. $[7,8]$ integrated these observations into a model that could accurately predict the effectiveness of trap-comb methods using worker and drone brood. In this paper we use this model to estimate and compare the effectiveness of different biotechnical control methods.

\section{MATERIALS AND METHODS}

\subsection{The trap-comb model}

\subsubsection{General}

Calis et al. [8] validated a trap-comb model based on the work of Boot et al. [3] on invasion rates of mites into brood cells. The observed effectiveness of trap-comb methods using worker or drone brood could be predicted using determined colony sizes and brood cell numbers in the trap- and non-trap-combs. Here, this model is used to estimate and compare the effectiveness of different trap-comb methods. Based on an initial number of 100 mites distributed over adult bees, worker brood and drone brood, the model calculates: 1) the number of mites that invade worker and drone brood cells in both the trapand non-trap-combs; and 2) the number of mites that emerge from brood cells of a standard colony on each day during a portion of the brood-rearing season. To best compare the evaluated biotechnical control measures, these calculations fall within a 70-day period. However, mite trapping with worker brood can be performed throughout the breeding season [7], whereas mite trapping with drone brood should be synchronized with the swarming season to ensure drone brood production [8]. 


\subsubsection{Invasion rate of mites into brood cells}

Boot et al. [3] derived empirical relationships between the invasion rate of mites into brood cells $\left(r_{w}\right.$ and $r_{d}$ for worker and drone brood, respectively) and the ratio of the number of available cells (number of cells capped per day) to the number of adult bees. These relationships may be expressed as:

and

$$
\mathrm{r}_{\mathrm{w}}=0.56 \mathrm{C}_{\mathrm{w}} / \mathrm{W}
$$

$$
r_{d}=6.49 C_{d} / W
$$

where $C_{w}$ and $C_{d}$ are the number of available worker and drone brood cells, respectively, and $\mathrm{W}$ is the weight in grams of adult bees in the colony. Depending on the weight of the colony, a specific number of brood cells that are being capped over 1 day are invaded by:

$$
M_{i}=M_{0}\left(1-e^{-\left(r_{w}+r_{d}\right)}\right)
$$

where $M_{0}$ is the number of phoretic mites and $\mathrm{M}_{\mathrm{i}}$ is the number of mites entering brood cells on that day. Since mites invade brood cells of both types simultaneously, $r_{w}$ and $r_{d}$ are summed to obtain the invasion rate in all brood cells. Invading mites are divided over worker and drone brood in proportion to the quantities $r_{w} /\left(r_{w}+r_{d}\right)$ and $r_{d} /\left(r_{w}+r_{d}\right)$, respectively [3]. An illustrative feature of the model is that with increasing num- bers of drone brood cells being capped the parasitic load in worker brood cells decreases. Another property of the model is the negative exponential relation between the rate of invasion and the number of mites that invade brood cells, which may explain why over a wide range of drone cells, trapping efficiency is practically the same [34]. In our model, mites invade brood cells in trap-combs or brood cells in the non-trapped combs of the brood nest. In the first case, the mites are trapped and removed from the colony. In the latter case, the mites emerge from the brood cells after the postcapping stage of the brood cell. It is assumed that 1.6 and 2.5 times the number of invaded mites emerge from worker and drone brood cells, respectively, reflecting the mite's reproduction [9].

To reach an effectiveness equal to a standard treatment (e.g. about $95 \%$ using Perizin), a relative brood cell invasion rate of $-\ln (0.05)=3.00$ per time unit is needed, assuming that all mites stay phoretically on the bees. The time unit reflects the period during which mites are trapped. Using the invasion rate equations, we can calculate that $3.00 / 0.00056=5350$ worker brood cells or $3.00 / 0.00649=462$ drone brood cells are needed 10 trap $95 \%$ of the mites in a broodless colony of $1 \mathrm{~kg}$ of bees. When a colony contains more bees and, thus, has a larger weight, a proportionally larger amount of brood cells is needed for the same trapping effectiveness (figure I),

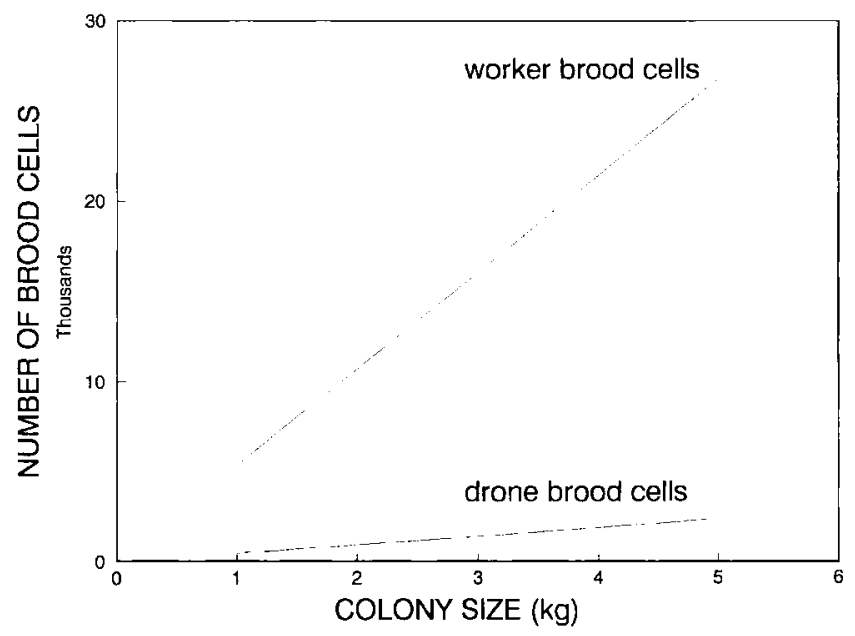

Figure 1. Numbers of worker and drone brood cells needed to trap $95 \%$ of the mites in relation to the weight of a broodless colony. 
irrespective of the time span during which they are capped [2]. In theory, invasion into brood cells in an area of the colony can be limited by the spatial distribution of the mites. Depending on the rate of redistribution of the mites, a higher invasion rate is expected when the availability of brood cells is extended over a longer period. For worker brood, however, Boot et al. [2] found no effect of different periods of brood cell availability on the invasion rate. For drone brood, Schmidt-Bailey and Fuchs [35] found a reduced invasion rate when large numbers of brood cells per bee were available during a shorter period. Considering the much lower number of brood cells that are capped per bee and per day in our simulations, the process of redistribution of the mites is expected to prevent an effect of the period of brood cell availability on the invasion rate.

\subsubsection{The standard bee colony and trap-combs}

The imaginary standard bee colony consists of 30000 bees $(3.75 \mathrm{~kg})$ and a brood nest that occupies an equal number of cells, of which $4 \%$ contains drone brood [9]. From these imaginary colony data we derived for the two types of brood cells the numbers of brood cells that are capped and left by the young bees each day. Using the model, we estimated the initial distribution of mites over adult bees, worker brood and drone brood to be $29: 48: 23$, respectively. If the queen produces worker brood for trap-combs, normal brood production stops. If the queen produces drone brood for trap-combs, normal brood production continues. Trap-combs are assumed to contain 5000 worker brood cells or 1500 drone brood cells.

\subsection{Evaluation of trap-comb methods}

The model is used to calculate the number of trapped mites and the remaining mites in the standard colony at the moment that the final trapcomb has been removed from the colony. The percentage of trapped mites is taken as a measure of effectiveness (table I), as is used in current research. However, applying trap-comb methods often implies indirect effects on population growth because trapped mites cannot contribute to population growth. Using the model, a comparison can be made between the popula- tion of mites after the use of biotechnical control measures and the mite population when no treatment was given. When the model is run without trap-combs the mite population grows exponentially (figure 2). A second measure of effectiveness is the relative reduction of the population size at the end of the simulation due to the biotechnical control treatment.

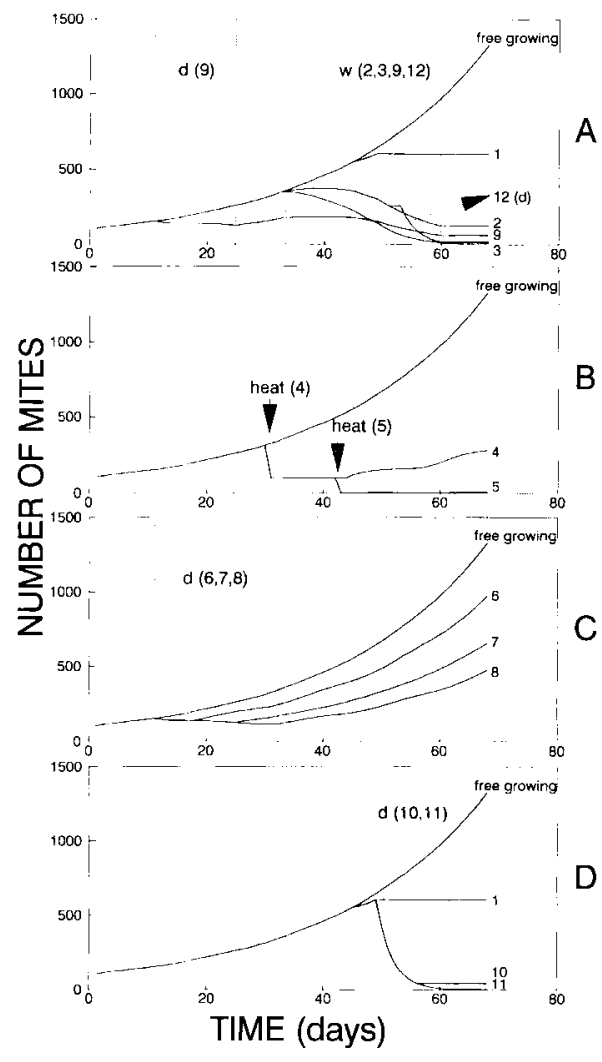

Figure 2. A-D) Simulations of mite populations during a period of 70 days with and without biotechnical control treatments. For each simulation, mites are trapped in either drone or worker brood (during the periods between the dotted lines d or w, respectively). A) In simulation 12 , the third trap-comb consists of drone brood and the queen is confined to empty combs on day 25. B) Heat treatment of capped brood. C) Trapping with drone brood within the brood nest. D) Trapping with drone brood during broodless conditions. 


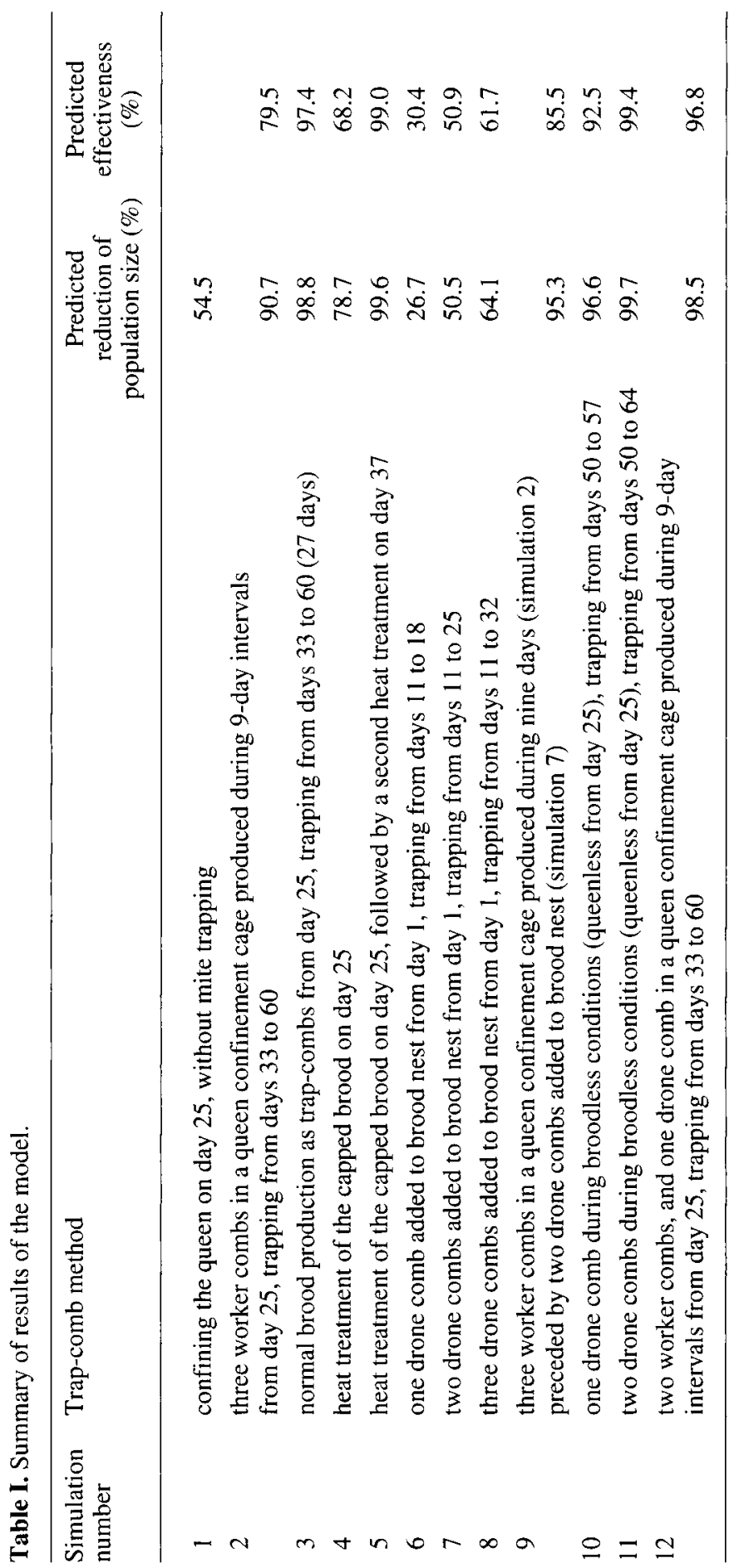




\section{RESULTS AND DISCUSSION}

Results of simulations of mite populations subjected to biotechnical control methods are visualized in figure 2 . The curves reflect the mite population present in the colony during the simulation, and mites are subtracted from the mite population as soon as they invade trap-combs. The effectiveness of the methods is summarized in table I. Each simulation is marked with a corresponding number used in the text, table I and figure 2 .

\subsection{Trapping mites with worker brood}

In all simulations using trap-combs with worker brood (table I: simulations 2, 3, 9 and 12), the queen is confined to empty combs on day 25. In the trap-combs, brood is produced at a constant rate, and mites are trapped starting on the day the first brood in the trap-combs is capped. When the queen is confined to one comb in a cage, the mite population will stop growing when the last mites emerge with their hosts from the remaining brood nest (simulation 1). Confinement of the queen restricts egg-laying to one comb at a time. Three of these combs produced in subsequent 9-day intervals ( $\mathrm{sim}$ ulation 2) trap $79.5 \%$ of the mites present in the standard colony. Since trapped mites cannot contribute to population growth, the population size is further reduced by $90.7 \%$ compared to the free-growing mite population. The use of more brood cells will increase the effectiveness of mite trapping with worker brood. This is feasible because the mites can be selectively killed and the worker brood saved. Fries [14] showed that capped worker brood between 9 and 18 days of age could be safely treated with formic acid outside the colony to kill the mites. Accordingly, Calis et al. [7] prepared batches of brood with trapped mites for formic acid treatment outside the colony by confining queens for three 9-day intervals to supers containing ten combs or queen confinement cages containing three combs. Hence, brood production was not limited by the number of cells and here (simulation 3 ) we assume that worker brood cells used for mite trapping are produced at the rate calculated from the standard colony. Therefore, simulation 3 is expected to reduce the mite population by more than $95 \%$. A test of this method [7] revealed a somewhat lower effectiveness. This lower effectiveness was expected because the brood to bee ratio was also lower compared to that of the standard colony chosen here (about 0.65 and 1.0 occupied brood cells per bee, respectively). When applying heat treatment (simulations 4 and 5), the manipulation needed to obtain batches of dated brood can be avoided because the complete brood nest can be safely treated [12]. One treatment (simulation 4) kills all the mites inside the brood cells and, thus, a significant portion of the mites. This treatment is visualized by the subtraction of mites killed by the heat treatment from the mite population (figure 2). When a second treatment is applied before newly capped brood cells emerge, the majority of the mites that remained on the bees after the first treatment will be killed since they will have invaded the newly capped brood cells (simulation 5).

Trapping with worker brood is labour intensive because a large amount of brood is needed to trap mites for effective control. Additionally, trapping with worker brood requires treatment of the capped brood to selectively kill the mites.

\subsection{Trapping mites with drone brood}

In all simulations using trap-combs with drone brood cells in colonies actively rearing brood (simulations 6-9), empty drone combs are introduced in weekly intervals starting from day 1 of the simulation. We assume that these drone combs obtain 1500 cells of drone brood which are produced within a 1 -week period, in addition to the 
existing brood nest, and that mites are trapped starting from the day the first drone brood in the trap-combs is being capped. When the bees are allowed to rear drone brood in combs that are removed before the drones emerge (simulations 6-8), large numbers of mites can be trapped. Differences between the population reduction and the trapping effectiveness (table I) are not only influenced by trapped mites that cannot contribute to population growth, but also by the model assumption that mites increase in numbers when they emerge from a brood cell. In the situation when one trap-comb of drone brood is removed, the trapping effectiveness is higher than the population reduction, because the majority of the mites that remain in the colony continue to reproduce inside brood cells. The population reduction compared to the trapping effectiveness increases again when more trap-combs with drone brood are removed (table I). Removal of trap-combs with drone brood temporarily stops population growth of the mites. Fries and Hansen [15] found that removal of drone combs preceding trapping with worker brood, using the queen confinement cage over one comb, considerably improved biotechnical control, as predicted with the model (simulation 9). In this simulation, two trap-combs with drone brood are removed before the queen is confined to the cage containing worker comb on day 25 . Many mites, however, invade the brood cells of the remaining brood nest and avoid the trap-combs with drone brood.

Broodless conditions that occur in colonies should be used to take advantage of the high invasion rate of the mites into drone brood cells. Accordingly, efforts have been directed towards integrating mite trapping in drone brood with swarm-prevention techniques $[8,10,23,34]$. Simulating a situation in which the queen has been removed from the colony (on day 25), it is shown that introducing one comb of drone brood to trap mites (simulation 10) after the last bees have emerged from the brood cells of the existing brood nest (from day 50), effectively reduces the mite population, while a second drone comb (simulation 11) practically eliminates the mite population. A broodless artificial swarm split from a colony will contain only a part of the phoretic mites present in the original colony and a trap-comb with drone brood will trap the majority of these mites. Accordingly, when the one-comb queen confinement cage is used, and during the third confinement interval, the queen is caged on a drone comb, the effectiveness of this trap-comb method (simulation 2) will drastically improve (simulation 12) [5, 26].

Compared to worker brood, trapping with drone brood demands many fewer brood cells for sufficient mite control, and removal and destruction of drone brood with trapped mites is common practice. Preparation of trap-combs with drone brood can quite easily be integrated into existing swarm-prevention techniques.

Calis et al. [7,8] successfully used knowledge on invasion behaviour of mites to predict the effectiveness of control methods based on trap-combs. Here we demonstrated that our model can be used to evaluate control scenarios encompassed by a diversity of bee-management systems.

Since brood cell invasion is crucial for mite reproduction, basic knowledge on the process of brood cell invasion also helps model $V$. jacobsoni population dynamics in a broader sense.

Integration of knowledge on brood cell invasion into the population dynamics model of Fries et al. [16], allowed more realistic modelling of $V$. jacobsoni populations, providing a tool to simulate not only biotechnical control methods, but also responses of mite populations to climatic conditions and honey bee traits [9].

\section{ACKNOWLEDGEMENTS}

We thank M. Beekman and J.C. van Lenteren, M.W. Sabelis and two anonymous referees for their valuable comments on versions of the manuscript. 
Résumé - Évaluation, à l'aide d'un modèle, des méthodes de lutte contre Varroa jacobsoni, basées sur le piégeage dans le couvain d'abeilles. Les méthodes biotechniques de lutte contre l'acarien Varroa jacobsoni Oudemans reposent sur le fait que les acariens sont piégés à l'intérieur des cellules de couvain et peuvent être éliminés de la colonie d'abeilles avec le couvain. Calis et al. [8] ont validé un modèle de rayonpiège basé sur le travail de Boot et al. [3] portant sur les taux d'invasion des cellules de couvain par les acariens. Le modèle est utilisé ici pour estimer et comparer l'efficacité des diverses méthodes utilisant le rayon-piège.

Le piégeage avec le couvain d'ouvrières requiert beaucoup de travail, car il faut un grand nombre de cellules de couvain pour piéger suffisamment d'acariens de façon à obtenir un niveau de lutte efficace. Il nécessite en outre le traitement du couvain operculé pour tuer sélectivement les acariens, car les apiculteurs ne veulent pas sacrifier le couvain d'ouvrières. Si l'on piège les acariens avec le couvain de mâles, on obtient un niveau de lutte efficace avec moins de cellules de couvain et la destruction du couvain avec les acariens est une pratique commune généralement acceptée. En outre, dans ce cas, la préparation des rayons-piège peut être intégrée aux techniques de prévention de l'essaimage et le temps supplémentaire nécessaire est faible. Le modèle fournit un outil pour prédire l'efficacité des stratégies de lutte biotechniques, sans recourir à des test gourmands en temps. La figure 2 visualise les résultats de la simulation des populations d'acariens soumises aux méthodes de lutte biotechniques. L'efficacité des méthodes est résumée dans le tableau $I$.

En général le modèle illustre l'utilité de connaître le comportement d'invasion. Puisque l'invasion des cellules de couvain est un point crucial pour le reproduction de $V$. jacobsoni, la connaissance de ce mécanisme facilite la modélisation de la dynamique des populations de l'acarien. L'intégration de cette connaissance au modèle de
Fries et al. [16] a permis de réaliser une modélisation des populations de V. jacobsoni plus proche de la réalité et a fourni un outil pour simuler non seulement les méthodes de lutte biotechniques, mais aussi les réactions des populations d'acariens aux conditions climatiques et aux caractéristiques comportementales des abeilles [9]. (c) Inra/DIB/AG!B/Elsevier, Paris

\section{Varroa jacobsoni / lutte biotechnique / rayon-piège / modèle / Apis mellifera}

\section{Zusammenfassung - Modellrechnungen} zur Abschätzung der Wirksamkeit der Fangwabenmethode zur Bekämpfung der Varroamilben in Bienenvölkern. Biotechnische Methoden zur Bekämpfung der Varroamilben machen sich die Tatsache zu Nutze, da $\beta$ die Milben während der Reproduktion in den Brutzellen eingeschlossen sind und durch Entnahme der Brut aus dem Volk entfernt werden können. Auf Grundlage der Arbeiten von Boot et al. [3] zur Befallsrate der Brutzellen entwickelten Calis et al. [8] eine Modellrechnung des Fangwabenverfahrens. Hier wird dieses Modell genutzt, um die Wirksamkeit unterschiedlicher Varianten des Fangwabenverfahren zu ermitteln und zu vergleichen.

Die Nutzung von Arbeiterinnenbrutwaben ist arbeitsaufwendig, da zur Erzielung einer ausreichenden Wirksamkeit eine große Menge von Brut benötigt wird. Da die Bienenhalter die Arbeiterinnenbrut retten wollen, erfordert dieses Verfahren zusätzliche Methoden zur Abtötung der Milben in der verdeckelten Brut. Die Nutzung von Drohnenbrutzellen erfordert weit weniger Brutzellen und die Vernichtung der Drohnenbrut mit den eingefangenen Milben ist eine allgemein akzeptierte Praxis. Darüber hinaus kann die Erzeugung von Drohnenbrutfangwaben in die Vorgehensweise bei der Schwarmverhinderung eingepasst werden und erfordert daher nur wenig zusätzliche Zeit. Unsere Modellrechnung stellt ein Mittel zur Vorhersage des Erfolgs von bio- 
technischen Bekämpfungsmethoden dar, ohne da $\beta$ aufwendige Testreihen durchgeführt werden müssen. Die Resultate der Simulationsrechnungen über die Entwicklung der Varroapopulationen unter verschiedenen Bekämpfungsmaßnahmen sind in Abbildung 1 dargestellt. Die Wirksamkeit der verschiedenen Anwendungweisen sind in Tabelle I zusammengefa $\beta$ t.

Das Modell unterstreicht den Nutzen einer genauen Kenntnis des Befallsverhaltens zur Ermittlung der Populationsdynamik von Varroamilben in Modellrechnungen. Die Einbeziehung des Befallsverhaltens in das Populationsmodell von Fries et al. [16] ermöglichte eine weit realistischere Modellrechnung der Varroapopulationen. Es stellt damit ein nützliches Werkzeug dar, mit dem nicht nur die Wirksamkeit biotechnischer Bekämpfungsmethoden, sondern ebenso auch das Verhalten von Varroapopulationen unter unterschiedlichen klimatischen Bedingungen nachvollzogen werden können [9]. $\odot$ Inra/DIB/AGIB/Elsevier, Paris

\section{Apis mellifera / Varroa jacobsoni / Fang- waben / biotechnische Methoden / Modellrechnungen}

\section{REFERENCES}

[1] Bolli H.K., Bogdanov S., Imdorf A., Fluri P., Zur Wirkungsweise von Ameisensäure bei Varroa jacobsoni Oud. und der Honigbiene (Apis mellifera L), Apidologie 24 ( 1993) 51-57.

[2] Boot W.J., Sisselar D.J.A., Calis J.N.M., Beetsma J., Factors affecting invasion of Varroa mites into honey bee brood cells, Bull. Entomol. Res. 84 (1994) 3-10.

13] Boot W.J., Schoenmaker J., Calis J.N.M., Beetsma J., Invasion of Varroa mites into drone brood cells of the honey bee, Apidologie 26 (1995) 109-118.

14] Buren N.W.M. van, Mariën J., Velthuis H.H.W., Oudemans R.C.H.M., Residues in beeswax and honey of perizin, an acaricide to combat the mite Varroa jacobsoni Oudemans (Acari: Mesostigmata), Environ. Entomol. 21 (1992) 860-865.

[5] Büchler R., Trapping combs with drone brood for the elimination of Varroa mites, in XXXVth International Apicultural Congress, Antwerpen, Programme and summaries of the reports, Apimondia, Bucharest, 1997, p. 83.
[6] Calis J.N.M., Schmidt-Bailey J., Beetsma J., Boot W.J., Eijnde J.H.P.M. van den, Fuchs S., Ruijter A. de, Steen J.J.M. van der, Successful trapping of Varroa jacobsoni with drone brood in broodless Apis mellifera colonies, Apiacta 32 (1997) 65-71.

[7] Calis J.N.M., Beetsma J., Boot W.J., Eijnde J.H.P.M van den, Ruijter A. de, Steen J.J.M. van der, Control of Varroa mites by combining trapping in honey bee worker brood with formic acid treatment of the capped brood outside the colony: Putting knowledge on brood cell invasion into practice, J. Apic. Res. (1999) in press.

[8] Calis J.N.M., Beetsma J., Boot W.J., Eijnde J.H.P.M van den, Ruijter A. de, Steen J.J.M. van der, Effective biotechnical control of Varroa mites: Applying knowledge of brood cell invasion to trap honey bee parasites in drone brood, J. Apic. Res. (1999) in press.

[9] Calis J.N.M., Fries I., Ryrie S.C., Population modelling of Varroa jacobsoni, Apidologie 30 (1999) 111-124

[10] Dung N.V.. Tan N.Q., Huan L.V., Boot W.J., Control of honey bee mites in Vietnam without the use of chemicals, Bee World 78(2) (1997) $78-83$.

[11] Engels W., Rosenkranz P., Hertl F., Staemmler G., Biologische Varroa-Kontrolle durch Drohnenbrutentnahme, Apidologie 15 (1984) 246-248.

[12] Engels W., Varroa control by hyperthermia, in: Matheson A. (Ed.), New Perspectives on Varroa, IBRA, Cardiff, UK, 1994, pp. 115-119.

[13] Fries I., Short-interval treatments with formic acid for control of Varroa jacobsoni in honey bee (Apis mellifera) colonies in cold climates, Swed. J. Agric. Res. 19 (1989) 213-216.

[14] Fries I., Treatment of sealed honeybee brood with formic acid for control of Varroa jacobsoni, Am. Bee J. 131 (1991) 313-314.

[15| Fries I., Hansen H., Biotechnical control of Var. roa mites in cold climates, Am. Bee J. 133 (1993) 435-438.

[16] Fries I., Camazine S., Sneyd J., Population dynamics of Varroa jacobsoni: a model and a review, Bee World 75 (1994) 5-28.

[17] Fuchs S., Untersuchungen zur Quantitativen Abschätzung des Befalls von Bienenvölkern mit Varroa jacobsoni Oudemans und zur Verteilung des Parasiten im Bienenvolk, Apidologie 16 (1995) 343-368.

[18] Fuchs S., Preference for drone brood cells by Varroa jacobsoni Oud. in colonies of Apis mellifera carnica, Apidologie 21 (1990) 193-199.

[19] Greef M. De, Wael L. de, Laere O. Van, The determination of the fluvalinate residues in the Belgian honey and beeswax, Apiacta 29 (1994) 83-87.

[20] Hansen H., Guldborg M., Residues in honey and wax after treatment of bee colonies with formic acid, Tidsskr. Planteavl. 92 (1988) 7-10. 
[21] Hansen H., Petersen J.H., Residues in honey and wax after treatment of bee colonies with bromopropylate, Tidsskr. Planteavl. 92 (1988) I-6.

122| Imdorf A., Charrière J.D., Bachofen B.. Efficiency checking of the Varroa jacobsoni control methods by means of oxalic acid. Apiacta 32 (1997) 89-91.

[23] Jenter K., Mit gezielter biologischer FrühjahrsSommer-Behandlung gegen die Varroa, Allg. Disch. Imkerztg. 20 (1986) 111-114.

[24] Koeniger N., Fuchs S., Control of Varroa jacobsoni: current status and developments, in: Needham G.R., Page R.E., Delfinado-Baker M., Bowman C.E. (Eds.), Africanized Honeybees and Bee Mites, Ellis Horwood Limited, Chichester, 1988 , pp. $360-369$.

[25] Kraus B., Berg S., Effect of a lactic acid treatment during winter in temperate climate upon Varroa jacobsoni Oud. and the bee (Apis mellifera L.) colony, Exp. Appl. Acarol. 18 (1994) $459-468$.

[26] Kruse G., Das Banwabenverfahren, Dtsch. Bienen J. 3 (1995) 19-21

[27] Lodesani M., Pellacani A., Bergomi S., Carpana E., Rabitti T., Lasagni P., Residue determination for some products used against Varroa infestation in bees, Apidologie 23 (1992) 257-272.

[28] Lodesani M., Colombo M., Spreafico M., Ineffectiveness of Apistan treatment against the mite Varroa jacobsoni Oud. in several districts of Lombardy (Italy), Apidologie 26 (1995) 67-72.

[29] Maul V., Empfelungen zur Methodik der Varroa Elimination mittels Bannwaben aus Arbeiterbrut, Allg. Dtsch. Imkerztg. 18 (1983) 179-183.

\section{APPENDIX: Detailed description of the trap-comb model}

The number of brood cells capped per brood type and per day in the brood nest was derived from the total number of brood cells in the standard colony. Worker brood trap-combs $(5000$ brood cells) used in our simulations were produced during 9-day queen confinement periods, whereas the drone brood trap-combs ( 1500 brood cells) were produced during 1 -week periods. The initial distribution of 100 mites over bees, worker brood and drone brood was estimated to be 29:48:23. At the start of one simulation day, the
[30| Maul V., Klepsch A., Assmann-Werthmüller U,, Das Bannwabenverfahren als Element Imkerlicher Betriebweise bei starkem Befall mit Varroa jacobsoni Oud, Apidologie 19 (1988) 139-154.

131| Milani N., Possible presence of fluvalinate-resistant strains of Varroa jacobsoni in northern Italy, in: Matheson A. (Ed.), New Perspectives on Varroa, IBRA, Cardiff, UK, 1994, pp. 87.

132] Ritter W., Ruttner F., Neue Weg in der Behandlung der Varroatose, Allg. Dtsch. Imkerztg. 14 (1980) 15l-157.

[33] Rosenkranz P., Thermobehandlung verdeckelter Arbeiterinnenbrutwaben als Möglichkeit der Varroatose-Kontrolle, Apidologie 18 (1987) 385-388.

1341 Schmidt-Bailey J., Fuchs S., Büchler R., Effectiveness of drone brood trapping combs in broodless honeybee colonies, Apidologie 27 (1996) 294

1.35| Schmidt-Bailey J., Fuchs S., Experiments for the efficiency of Varroa control with drone brood-trapping combs, Apidologie 28 (1997) 184-186.

[36] Schulz A., Koeniger N., Ruttner F., Drohnenbrut als Varroafulle, Allg. Dtsch. Imkerztg. 17 (1983) 52-54.

[37] Schulz A.E., Reproduktion und Populationsentwicklung der parasitischen Milbe Varroa jacobsoni Oud. in Abhängigkeit vom Brutzyclus ihres Wirtes Apis mellifera L., Apidologie 15 (1984) $401-420$.

[38] Sulimanovic D., Ruttner F., Pechhacker H., Studies on the biology of reproduction in Varroa jacobsoni (in Japanese), Honcybee Sci. 3 (1982) $109-112$.

derived numbers of brood cells that would be capped during that day and the colony size ( 3.75 $\mathrm{kg}$ ) were used to calculate the invasion rate into brood cells, the number of phoretic mites invading brood cells, and the distribution of mites over both types of brood cells within the trap-combs or brood nest (non-trap) combs. In contrast to mites invading cells in the brood nest, mites invading trap-combs are removed from the colony. Emergence of mites and their offspring (equaling the number of invaded mites times 1.6 and 2.5 for worker and drone brood cells, respectively), follows a sequence analogous to invasion, delayed with the duration of the capped 
honey bee brood stage. At the end of one simulation day these emerging mites are added to the phoretic mites. Then a new simulation day starts. Calculations were performed using a spreadsheet. At the moment the final trap-comb was removed from the colony, the percentage of trapped mites was calculated. After 70 days the population size was calculated and could be compared to a free-growing population.

The following formulas were used.

1) Invasion rate into worker brood cells:

$$
r_{w}=0.56 * \mathrm{C}_{w} / \mathrm{W}
$$

where $r_{w}$ is the invasion rate into worker brood cells per day, $\mathrm{C}_{\mathrm{w}}$ is the number of worker brood cells that are capped during 1 day, and $W$ is the weight of the bees of the colony in grams.

2) Similarly, the invasion rate into drone brood cells:

$$
r_{d}=6.49 * C_{d} / W
$$

3) Number of invading mites:

$$
M_{i}=M^{*}\left(1-e^{-\left(r_{w}+r_{d}\right)}\right)
$$

where $\mathrm{M}$ is the number of phoretic mites, and $M_{i}$ is the number of mites that invade per day.

Brood cells on both trap-combs and combs of the brood nest are invaded in proportion to the numbers of capped brood cells on either type of comb. Mites that invade trap-comb brood cells are removed from the colony, whereas mites that invade the brood nest will emerge after the postcapping period.

4) Mites invading worker brood:

$$
\mathrm{W}_{\mathrm{i}}=\mathrm{M}_{\mathrm{i}}{ }^{*} \mathrm{r}_{\mathrm{w}} /\left(\mathrm{r}_{\mathrm{w}}+\mathrm{r}_{\mathrm{d}}\right)
$$

where $\mathrm{W}_{\mathrm{j}}$ is the number of mites invading worker brood cells per day.

5) Mites emerging from worker brood:

$$
\mathrm{W}_{\mathrm{e}}=1.6^{*} \mathrm{~W}_{\mathrm{i}, 1-12}
$$

where $W_{c}$ is the number of mites emerging from worker brood cells per day.

6) Similarly, mites invading drone brood:

$$
D_{i}=M_{i}^{*} r_{d} /\left(r_{w}+r_{j}\right)
$$

7) Mites emerging from drone brood:

$$
\mathrm{D}_{\mathrm{c}}=2.5 * \mathrm{D}_{\mathrm{i}, 1-14} \text {. }
$$

